\title{
COMPETENCE AND MEDIA COMPETENCE IN THE AGE OF THE THE INTERNET
}

\author{
Branislav Banićc ${ }^{1 *}$ \\ Ilija Banić2, \\ Siniša Jovanović ${ }^{3}$, \\ Milica Andevski ${ }^{4}$, \\ Pavle Stojanović ${ }^{3}$ \\ ${ }^{1}$ Faculty of Physical Education and \\ Sports Management, \\ Singidunum University, \\ Belgrade, Serbia \\ ${ }^{2}$ Faculty of Sport and Physical Education, \\ Leposavić, Serbia \\ 3Primary School „,Milan llić Čiča", \\ Aranđelovac, Serbia \\ ${ }^{4}$ Faculty of Philosophy, \\ University of Novi Sad, \\ Novi Sad, Serbia
}

\begin{abstract}
:
The concepts of media competence have different meanings, and the media competence itself most often refers to: understanding media messages and content; ruling the media, ie the skill of handling media devices; effective use of the media in solving school and business tasks (the ability to plan and enjoy free time with the help of the media); creating the media, composing media messages and offers; evaluating of the media, ie the functions of the media system. Media competence in this sense implies the ability to encompass social relations and (re)evaluate one's own actions according to normative and ethical as-pects.
\end{abstract}

\section{Keywords:}

competence, media, media competence, internet

\section{INTRODUCTION}

The term media competence runs in different ways through a bunch of analyzes and debates in different fields: not only in science (biology, linguistics, sociology, psychology, pedagogy), but also in politics, law or economics, and therefore the term becomes vague and ambiguous. In a certain context, it is necessary to specify what is meant by it, and also it is very help ful first to analyze the very concept of competence in general. Unlike the term media competence, the broader notion of competence has a longer history. This history of the develop-ment of competence theories can be divided into three phas-es: 1 . linguistic definition of the term competence during the 70s, 2. introduction of the concept of competence in various theories of development and socialization and 3. its use in sociological analyzes of socialization and society during the $80 \mathrm{~s}$. Research focused on competency theories has had to face many problems. There have already been many ambiguities [1] about the exact meaning of the term competence, which is divided into the mentioned three phases. 
In the social sciences, the term competence is associated with the research in linguistics by N. Chomsky. According to Chomsky, Linguistic competence presents intuitive knowledge of the rules available to subjects and is described by the grammar of one language. When children learn a language, they must have generative grammar, i.e. the method how to create a customized grammar from the given primary linguistic data. Thereby, they are innate, individual predis-positions, which are on a synchronous level.

Focusing on intrasubjective constructions of competencies led to a sociological study of socialization. In addition to the "linguistic turn“ in the social sciences, structuralgenetic theories of competence encouraged J. Habermas to take up the term competence in the theory of connecting socialization and socio-theoretical perspectives. At the socialization-theoretical level, it is about connecting the sociological theory of personal identity creation with psychological theories of cognitive, social and moral development (among others, with the theories of Piaget, Selman, Kohlberg). The „guide“ was the opinion that subjects develop their competencies in social interactions. In this context, Habermas talks about role competence, interaction competence, but also about communicative competence. Subjective competencies are always adopted within the development of communicative competence, and this again as a prerequisite has constant participation in the communication processes. This reverses the developmentalpsychological relationship between subjective and social structures: the processes of social interactions are the ones that accelerate and organize the process of creating subjective competencies.

The concepts of media competence can have very differ-ent meanings:

- Understand the media: media competence may refer to un-derstanding media messages and content.

- Rule the media: media competence may refer to the skill of handling media devices.

- Use the media: media competence may refer to the effective use of the media in solving school and business tasks. It may also be expressed in the ability to plan free time with the help of the media and enjoy it.

- Create the media: media competence may refer to compos-ing media messages and offers.

- Evaluate the media: media competence may finally relate to the functions of the media system. The media competence in this sense implies the ability to include social relations and (re)evaluate its own actions according to normative and ethi-cal aspects [2] [3].
The concept of competence is not only a long-standing topic in the media-pedagogical discussion. In recent years, it has been intensively considered through its practical pedagogical contributions. The discourse of pedagogical competence has developed in two directions:

1. Within the discussions about educational standards, the relatoinship with the models of competence has become a central aspect of the discourse on education planning and school development. Competence models concretize the contents and levels of general education and thus gain central importance for the problems of construction and legitimacy of current debates on education and curriculum.

2. Lately, the concept of competence has been intensively dealt with in the context of adult education. The discourse on competence here excludes the theory of „key qualifications" and emphasizes the importance of lifelong learning and the related necessity of self-regulatory life management. Replacing the term qualification with the term competence indicates a social change of the $20^{\text {th }}$ century, which is characterized by the individualization of life circumstances. Qualifications as objective measurement units that describe what one can, so to speak, for a lifetime, are becoming increasingly dysfunctional in a society characterized by rapid technological change. When professional requirements change rapidly, adjustment efforts are constantly needed, which require self-organized action, as well as dispositions of self-organization, and non-formal and lifelong learning.

Erpenbeck and von Rosenstiel understand competencies as dispositions of self-organization in a model of class competencies, which starts from the fact that self-organized action relates to the person who acts $(\mathrm{P})$ and is more closely determined through the activity and will components of the one who acts $(\mathrm{A})$. In addition, it refers to the material environment and its professionalmethodological understanding and change $(\mathrm{F})$ and to the social environment - that is, to other people or a group of people (S). Thus, the classes of competencies differ as follows:

- (P) Personal competencies: dispositions of a person to act reflexively and self-organized, ie. to assess oneself, to develop productive attitudes, systems of values, motives and auto-stereotypes, to develop one's own talents, motivation, intentions and to develop creatively and learn within and outside work. 
- (A) Competencies of activities and realization: dispositions of a person to work actively and self-organized and to direct this action to the realization of intentions and plans - either for themselves or for others or with others, in a team, in a company, in an organization. These dispositions imply the ability to integrate one's own emotions, motivation, abilities and experiences and all other competencies - personal, professional-methodical and social-communicative - into one's own will and successfully realize deeds.

- (F) Professional-methodical competencies: disposition of a person to act spiritually and physically selforganized when solving problems, ie. to solve problems creatively using professional and instrumental knowledge, abilities and skills, to rank rationally and evaluate knowledge; this includes the disposition that activities, tasks and solutions are shaped methodically self-organized and that methods are developed creatively.

- (S) Social-communicative competencies: dispositions to act communicatively and cooperatively selforganized, ie. to discuss creatively with others, to act as a team and to develop new plans, tasks and objectives.

As we have already indicated, the debate on competence in media pedagogy had its own tradition even before the current discourse in pedagogy. This comes from Dieter Baacke [4], who referred to Habermas' „communicative competencies“, in the 1970s [5]. The classical formulation proposed by Baacke distinguishes the following areas of media compe-tence:

- Media criticism, the ability to analyze media content analytically, ethically and reflexively;

- Media science as knowledge about the media in terms of information about the media system, as well as the ability to use media technologies within the instrumental qualification capacity;

- Use of media, both through the reception and as a sender;

- Innovative and creative media action (media creation, innovative media systems.

If we compare this view with the classes of competencies cited by Erpenbeck and von Rosenstiel, we can conclude the following: Baacke's concept of media competence, which is not proved cognitively-theoretically, but activity-theoretically - related to communicative action - comes to very similar dimensions of competence: media criticism, in which individuals are reflexive towards the media, is closely linked to the personal competencies of Erpenbeck and von Rosenstiel. Here, too, it is about attitudes, views of the world, motives and autostereotypes within the encounter with the media. The science of media refers to professional-methodical competencies - that is, to the dispositions of a person to act self-organizedly in solving specific problems. The use of media is closely linked to Erpenbeck's and von Rosenstiel's competencies oriented to the activity and implementation, which are based on the ability to achieve motivation, skills and experiences through action. Finally, the creation of the media is close to social-communicative competencies, which is about how to collaborate creatively with others in order to implement joint plans.

Moser's understandings of media competence [6] are largely compatible with the model of Erpenbeck and von Rosen-stiel, because he also bases the competence model on four groups of competencies, the details of which are modeled somewhat differently (Figure 1):

Technical competence

- Ability to perform simple maintenance and installation tasks on media devices (battery replacement, software installation, removal of light failures, etc.).

- Handling the basic functions of media devices (hardware and software) in terms of user competencies.

- Thinking in simple programming and navigation schemes (programming remote control, adapting text to personal needs, controlling internet addresses, using browsers, etc.).

- Understanding professional terms.

Cultural competence

- Openness and curiosity towards the offers of new media as a part of modern everyday culture, but without uncritical and euphoric adoption.

- Competence to use not only literary and auditory, but also visual information.

- Development of orientation competence in the world of redundant information (eg in terms of knowledge management).

- Multicultural competence of movement in different spheres of the globalized world.

- Ability to deal with new forms of media communication creatively.

Social competence

- Possibility of competent behavior within mediated types of connections and communication schemes.

- Ability to deal with a mixture of real and virtual connec-tions.

- Ablity to adapt to new forms of organization and content of work within the information society (eg telework, forms of action and work based on the Internet, etc.). 


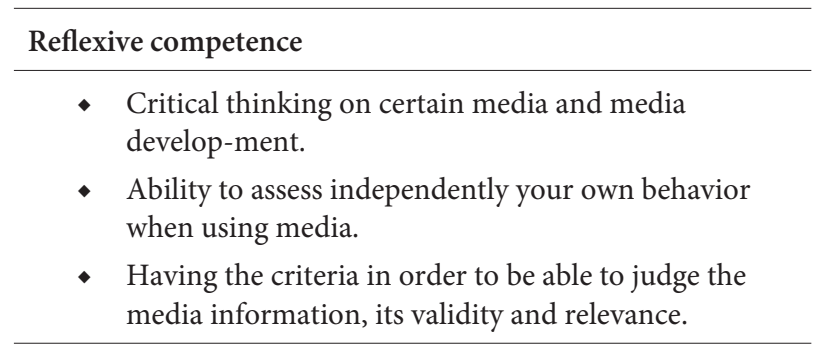

Figure 1. Model of media competence [6]

\section{MEDIA-PEDAGOGICAL MODELS OF COMPETENCE IN THE SCHOOL CURRICULUM}

Previous thoughts have followed the concept of media competence, which is not primarily related to the field of educa-tion and media-didactic issues, so we will try to establish a media-pedagogical connection between the issue of educational standards and the concept of competence. Here we point out that media pedagogy is not a school subject, but we look at it as extra-subject and integrative. This refers to topics in which, in proportion to the orientation of media pedagogy, an integrative concept is required in which the hitherto separate concepts of reading, watching television or basic infor-mation education are combined [7]. Basic knowledge related to the media is designed interdisciplinary, primarily because it is useful in a variety of school subjects. Thus, „,media education“ and ,informatics“ in the curriculum of the Swiss canton of Zurich is one of interdisciplinary subjects. The double meaning of media-pedagogical topics is clearly described: For the school, information technology and communication technology are a tool and a teaching subject at the same time [8]. Media pedagogy is therefore something like an ,interdisciplinary subject“ at school - or a transversal topic.

Based on that, it is clear that - in terms of discussion about the standard of education - media-pedagogical content refers to knowledge specific to a certain domain, but in terms of average competence, it cannot be limited only to that. Media pedagogy proves that there is a peculiarity that does not ap-pear in the traditional canon of subjects - and which is still relevant to school education. The growing importance of digital media for learning and school means that it is important to formulate standards for these domains, which all students could reach.
The double relation of media pedagogy with disciplinary and interdisciplinary contents does not make the discussion of the standard of education in this field any easier. Some authors such as Hartung point out that there is a consensus that media education should be indirectly transferred through all subjects, in order to build and expand media competence in specific teaching contents. But at the same time, he remarks: „As to the question, whether there should be an additional, independent subject on media education, there are divergent opinions" $[9, \mathrm{p} .13]$.

The author Tulodziecki, in an attempt to formulate the standards of education in the field of media, faces the same di-lemma, but finds an interesting way out: on the one hand, he sees the possibility of formulating educational standards according to the fields and areas of media competence, ie. according to dimensions and partial competencies [10]. He sees as a danger that content specific to the media could lose its seriousness and form and be seen as second-rate. There-fore, as an alternative, he formulates the possibility of structuring according to the type of media - with the advantage of taking into account the specifics of the types of media. For him, two models of competence arise from this - one based on the types of media as domains of media use and the other which defines the fields or areas of media competence as superior. The di-vision according to the types of media means that the areas of competence are „print media“, ,,audio-visual media“ and „computer and internet“. This seems problematic for several reasons:

- It is obvious that the print media are closely linked to the teaching of the mother tongue, because that is exactly the subject, which has been connected with the media from the very beginning. While there are obvious connections of interdisciplinary areas of media with the traditional school subject, this is not the case with the other two types of media. Thus there is a danger that the associated standards will move in a vacuum.

- „Types of media“ are generally non-permanent subjects, which are interconnected in various ways and change very quickly from the point of view of digital media. Today, watching television is also done via computers, as well as reading newspapers; and it is likely that the previously divided media will merge so much with each other in the near future that the traditional boundaries between them will disappear. In this sense, it would be a conservative prejudice if these traditional categories were taken as a principle of structuring a progressively oriented curriculum. 
- Thirdly, the question is to what extent the competencies are specific to the current types of media. Precisely because separate media are increasingly digitally interconnected, interdisciplinary competencies have become important in many types of media. Visual competencies, which are used to interpret images, are used in a similar way in the types of media newspapers / magazines, television and the Internet.

For this reason, approaches based on interdisciplinary competence should be favoured. At the Faculty of Teacher Education in Zurich, a model has been developed that links the media competence as a broad medial field of action with personal competence of action (Figure 2) [11].

\begin{tabular}{|c|c|c|c|c|}
\hline & & \multicolumn{3}{|c|}{ Personal competence } \\
\hline \multirow{4}{*}{ 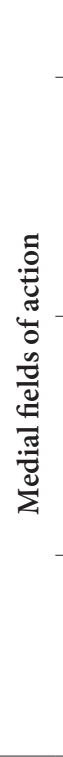 } & & $\begin{array}{l}\text { Professional } \\
\text { competence }\end{array}$ & $\begin{array}{l}\text { Methodological } \\
\text { competence }\end{array}$ & $\begin{array}{c}\text { Social } \\
\text { competence }\end{array}$ \\
\hline & $\begin{array}{l}\text { Applica- } \\
\text { tion and } \\
\text { creation } \\
\text { of media } \\
\text { products } \\
\text { (A) }\end{array}$ & A1.1 stadard & A1.2 standard & A1.3 stadard \\
\hline & $\begin{array}{l}\text { Exchange } \\
\text { and } \\
\text { mediation } \\
\text { of media } \\
\text { messages } \\
\text { (B) }\end{array}$ & B1.1 stadard & B1.2 standard & B1.3 stadard \\
\hline & $\begin{array}{l}\text { Reflection } \\
\text { and } \\
\text { criticism of } \\
\text { the media } \\
\text { (C) }\end{array}$ & C1.1 stadard & C1.2 standard & C1.3 stadard \\
\hline \multicolumn{3}{|c|}{ Level of competence 1} & of basic level (e & of $2^{\text {nd }}$ grade) \\
\hline \multicolumn{3}{|c|}{ Level of competence 2} & $\begin{array}{l}\text { d of intermedia } \\
\text { d of } 6^{\text {th }} \text { grade) }\end{array}$ & level \\
\hline \multicolumn{3}{|c|}{ Level of competence 3} & $\begin{array}{l}\text { nd of } 8^{\text {th }} \text { school } \\
\text { evel I }\end{array}$ & ear Secondary \\
\hline \multicolumn{3}{|c|}{ Level of competence 4} & $\begin{array}{l}\text { End of } 11^{\text {th }} \text { sch } \\
\text { Secondary leve }\end{array}$ & li year \\
\hline
\end{tabular}

Figure 2: Zurich competence model [11]

Similar to the concept of Erpenbeck and von Rosenstiel, this model starts from the key competencies of media action, which are important in most domains, ie. school subjects. Knowledge specific to the media is not excluded, because it is explicitly stated under the title "professional competence“. It needs to be further discussed whether it is adopted in a single subject or integrated into different subjects of the curriculum.
In the model briefly described here (Figure 2) we start from following understandings:

- The field of action is, concerning content, structure by media-pedagogical domains; from the point of view of the actor (teachers and students), they define the field of learning and teaching the media. In the presented model, three spheres are specified:

a) Application and creation of media products (and thus the use of "production media").

b) Exchange and mediation of media messages (ie the area of handling ,,communication media“).

c) Reflection and the criticism of the media (as a domain-specific field of action, which has always stood out as an important subject of media pedagogy since the 1970s).

- The real model of competence is based on these three areas of action and is followed by three areas of competence, namely

1. Professional competence in which declarative knowledge is collected, ie. professional and conceptual knowledge, which must be acquired for the purpose of competent action in certain fields.

2. Methodological competence, ie procedural knowledge or. techniques and knowledge of the rules, which serve to work competently with the media.

3. Social competences, ie medially reformed social rules, the mastering of which is necessary for the purpose of competent exchange and cooperation with the media.

Competencies are upgraded in one level model, whereby four levels of competencies are defined. The graded structure allows media competence to be defined as a developmental task for students.

\section{MEDIA COMPETENCES IN THE AGE OF THE INTERNET}

It would be problematic to view media competences and related educational standards primarily under the aspect of learning to test. Thus, those dangers that Tulodziecki connects with the definition of educational standards could arise:

- Dominance of set goals to the detriment of student participation and process orientation;

- Orientation towards taking exams instead of connection with interdisciplinary ideas of upbringing and education; 
- Orientation towards current requirements instead of orientation towards the future, which would be important given the rapid development in the field of information and communication technology;

- Dominance of uniform requirements towards the view of individual development of competencies within the biographical process.

The essence of this is that there is a danger that media competences are defined through qualification standards as products of school teaching that can be achieved, no longer in the sense that Erpenbeck and Sauter [12] define as the ability to think and act selforganized, as dispositions of selforganization. In such a context, teaching with digital media is less directed towards narrowly formulated learning objectives, but towards ,didactics of guidance“, which, generally speaking, starts from the open action of the teaching-learning process [13]. For professional knowledge, which is mainly dispro-portionately represented in the tests, this means: that the facts are not simply learned by heart and activated mechanically, but that the acquisition of knowledge is seen in close connection with the building of the ability to act [14].

This orientation of media competences towards the dispositions of self-organization is not important only because the learning styles through which young people face digital media are starting to change. Primarily in the Anglo-Saxon area under the terms „Netgeneration“, „,Google generation“, „Homo Zappiens“, „,Digital Natives“, „Producer“, etc. there are a multitude of approaches that describe this development. Accord-ing to Cross, the decisive feature is that learning is increasingly moving from the push principle to the pull principle. Learning is less and less program-oriented, and tries to respond to changes that occur within the uncertain perspective of the future. Those who deal with digital media learn more by trying, experimenting or using a social network. Targeted drafting of instructions or conducting a formal course on the introduction to a new program rarely happens today - which has the consequence that digital media providers (either hardware or software) today, as a rule, hardly attach instructions to their products. At the same time, the locus of control, which has been determined by teachers in traditional teaching, is increasingly shifting to the complex arrangements of students, coaches, lecturers, technology and resources [15].

\section{CONCLUSION}

For today's generation of students and lecturers, the impor-tance of the school for the transfer of media competencies must not be overestimated. Children and youth intensively use the media, primarily in extracurricular everyday life, and "Netgeneration“ also adopts many media competencies that it currently has at its disposal. But then what is left of the school's educational efforts in this regard? If students in ex-tracurricular activities adopt media competence that enable them to conquer the world of computers on their own within the framework of self-organized learning, one might wonder whether the efforts of the school are still needed at all. Never-theless, we conclude that there are numerous arguments advocating the sustainable use of computers at school.

More frequent use of computers at school is required, because everyday use of them at home puts the need for enter-tainment in the foreground: playing computer games, sharing and downloading music, watching videos, chatting via MSN, etc. On the contrary, working on a computer in professional everyday life sets other focuses: texts are processed, data-bases are worked on, creative software is used, photos are processed, etc. The task of school could be to fill in the gaps and work systematically with the software, which are not in use during free time - such as Office programs, image and movie editing programs, etc. Professional knowledge and reflective knowledge of the information society and the risks of working with technology could be a program for digital media education in schools. These are areas that no one in society cares about and that are not learned automatically by everyday computer use (for example, in working with Web 2.0, there are constant warnings that children and young people carelessly handle personal data on their profiles) [16].

Also, we must go beyond the issue of protection and gaps in knowledge and skills and start from the fact that the computer and the Internet belong to the everyday life of children and young people to such an extent that related media competences represent a resource that the school should use much more. If the media competence is viewed from the angle of self-organization competencies, then in the school context of learning, tasks should be set that enable the simultaneous application of media competences, differentiation of abilities and development of own competencies during the practice of self-organized learning. Therefore, it is less about transferring clearly defined and prescribed skills of working with digital 
media in terms of mediation didactics, and more about encouraging independent learning processes within the didactics of enabling that allow both informal and selfdidactic learning with / and / about media, which are included as a source in school learning.

This particularly suits the requirements associated with Web 2.0. Such learning spaces ,translate" the interactive $\mathrm{Web}$ into the context of the student experience and provide encouragement and motivation not to consume this Web passively. For this reason, Erpenbeck and Sauter focus on the development of online competence and emphasize „new blended Learning “ within Web 2.0. because the use of social software provides an opportunity to interconnect the methods of creative problem solving (professional and methodological competence), self-reflection (personal competence), social perspectives / views and worldviews (social competence) and individual actions (activity competences) [17].

If a school fails to accept the media competence of its students, which they bring from everyday life, and to create learning environments in which they can be used, then in the work with digital media there is a gap between school and non-school everyday life: Google generation implicitly conveys that their (extracurricular) media competences have nothing to do with that area, which is traditionally called education. And that means that significant opportunities for learning are gambled away - and that the development of media competences in the domains that increasingly determine the chances for a job and career in the information society is neglected. Montgomery presents alternatives to the education system: either the teaching will remain as it is - and we are still wondering why the school can no longer reach the world of young people, who belong to the „Digital Natives“. Or we will follow them and offer students a digital learning environment that suits them, because it belongs to the life that determines the everyday life of new generations in today's society. Networked media at school will then soon become as central in teaching as information and communication technologies in the world of work.

Schelhowe points out that children and young people should be given the opportunity to use digital media spontaneously and in a fun way that characterizes their imagination, ,by experiencing new ways of learning, experiencing the processes of emergence and thus taking responsibility" $[18$, p. 180]. This does not only apply to the technical and IT side of working with the media in this way we should also work with the Internet; and students in school should be given the opportunity to try out the application of Web 2.0 by actively participating in a blog, collaboratively creating text using a wiki, including photos and movies in school projects, and so on. Thus, it is not the basic IT education that is understood by media competence in terms of learning for testing, but the application of digital media in various school settings - such as decision-making, creation and reasoning, all in the context of the perspective for E-Learning at school.

\section{REFERENCES}

[1] M. Andevski, D. Ristić, Obrazovanje za menadžment, Novi Sad, CEKOM-books, 2010.

[2] H. Moser, Die Medienkompetenz und die 'neue' erziehungswissen schaftliche Kompetenzdiskussion, U: Herzig,B.,Meister,M.D.,Moser, H., Niesyto, H.,(Hrsg.) Jahrbuch Medienpädagogik 8. Medienkompetenz und Web 2.0. Wiesbaden, S. 59 - 81. 2010.

[3] H. Moser, Einführung in die Netzdidaktik. Lehren und Lernen in der Wissensgesellschaft. Hohengehren: Schneider, 2008.

[4] J. Habermas, Vorbereitende Bemerkungen zu einer Theorie der Kommunikativen Kompetenz. U: Habermas, J. Luhmann, N (Hrsg.) Theorie der Gesellschaft oder Sozialtechnologie-Was leistet die Systemforschung? Frankfurt/M: Suhrkamp, S. 101-141, 1971.

[5] D. Baacke, Kommunikation und Kompetenz. Grundlegung einer Didaktik der Kommunikation und ihrer Medien. München: Juventa, 1973.

[6] H. Moser, Die Medienkompetenz und die 'neue' erziehungswissen schaftliche Kompetenzdiskussion, U: Herzig,B.,Meister,M.D.,Moser, H., Niesyto, H.,(Hrsg.) Jahrbuch Medienpädagogik 8. Medienkompetenz und Web 2.0. Wiesbaden, S. 59 - 81. 2010.

[7] W. Wagner, R. Peschke, Auf dem Weg zu Bildungsstandards? Rück blick auf 20. Jahre, „Neue Tehnologie und Schule“. U: Computer + Unterricht, 63/2006, S. 6-11. 2006.

[8] Lehrplan für die Volksschule des Kantons Zürich, Zürich, 2000.

[9] R. Hartung, Standards für die Medienbildung? Anmerkungen zu Medien und Bildungsstandards, $\mathrm{U}$ : Computer + Unterricht, 63, S. 12-13, 2006.

[10] G. Tulodziecki, Medienbildung-welche Kompetenzen Schülerinnen und Schüler im Medienbereich erwerben und welche Standards sie erreichen sollen. U: Winkel, J. (Hrsg.) Standards in der Medienbildung. PLAZ-Forum, Heft 16. Paderborn, S. 9-34, 2007.

[11] H. Moser, Einführung in die Netzdidaktik. Lehren und Lernen in der Wissensgesellschaft. Hohengehren: Schneider, 2008. 
[12] J. Erpenbeck, W. Sauter, Kompetenzentwicklung im Netz. New Blended Learning mit Web 2.0. Köln: Lucherhand, 2007.

[13] M. Andevski, J. Arsenijević, M. Maljković, Computer in media-didactic discourse, Proceedings of 6th International Tehnology, Education and Development Conference, INTED,5-7. March, Valencia, Spain, 2012.

[14] U. Montgomery, Interneträume für „Digital Natives" in der Schule. U: Landesmedienzentrum Baden-Württemberg (Hrsg.) E-Learning in der Praxis. Eine Publikation der Medienoffensive II (Baden-Württemberg). Karlsruhe: Landesmedienzentrum BW, S. 29-31, 2008.
[15] R. Arnold, Ich lerne, also bin ich. Eine systemisch-konstruktivistische Didaktik. Heidelberg: Carl-Auer, 2007.

[16] H. Schelhowe, Technologie, Imagination und Lernen. Münster: Waxmann, 2007.

[17] R. Schulz-Zander, G. Tulodziecki, d. Bender, Dietmar, Veränderung von Unterricht mit digitalen Medien. U: Landesmedienzentrum Baden-Württemberg (Hrsg.) E-Learning in der Praxis. Eine Publikation der Medienoffensive II (Baden-Württemberg). Karlsruhe: Landesmedien zentrum BW, S. 9-14. 2008.

[18] J. Erpenbeck, W. Sauter, Kompetenzentwicklung im Netz. New Blended Learning mit Web 2.0. Köln: Lucherhand, 2007. 